\title{
Oral Hygiene Practices and Bottle Feeding Pattern Among Children with Early Childhood Caries: A Preliminary Study
}

\author{
Buhari $\mathrm{N}^{1}$, Zainal Abidin $\mathrm{FN}^{1}$, Mani SA${ }^{2}$, Khan $\mathrm{IM}^{3}$ \\ ${ }^{1}$ Formerly, Faculty of Dentistry, University Malaya \\ ${ }^{2}$ Lecturer, Department of Paediatric Dentistry and Orthodontics, Faculty of Dentistry, University of Malaya, \\ ${ }^{3}$ Post graduate student/Research assistant, Department of Paediatric Dentistry and Orthodontics, Faculty of \\ Dentistry, University of Malaya, Malaysia.
}

\begin{abstract}
The purpose of this study was to assess the association of bottle feeding and oral hygiene practices with the severity of caries among 3 to 5-year-old children with Early Childhood Caries (ECC). This cross-sectional study was carried out on pediatric dental patients with ECC attending a public university hospital. The parents or guardians were interviewed for the bottle-feeding pattern and oral hygiene practices followed by a clinical dental examination of their children with ECC. Data analysis was done using Chi squared test. Out of 32 children, $69 \%$ had severe early childhood caries with mean dft of 8.88 . In this study, $87.5 \%$ of the subjects had a history of bottle feeding, with $53.1 \%$ still being bottle fed at the time of study. Current bottle-feeding habit was found to be statistically significant with the severity of caries $(p=0.021)$. Majority (69\%) of the children were introduced to tooth brushing only after 1 year of age. About $40 \%$ of the children consumed either pre-chewed rice and/or shared spoons or feeding utensils with their parents or siblings but there was no significant association with the severity of caries $(p=1.00)$. Because of its association with ECC, prolonged bottle feeding is significantly associated with the severity of caries in our study population. Besides, vertical and horizontal transmission of bacteria was also a risk factor for ECC, but it did not show any significant association with severity of ECC.
\end{abstract}

Keywords: Bottle-feeding, dental caries, decayed, filled, dft, Early Childhood Caries, feeding pattern, nursing bottle, oral hygiene practices.

\section{Introduction}

Early Childhood Caries (ECC) is a virulent form of dental caries affecting babies and preschool children worldwide. Itis a multifactorial disease mostcommonly associated with poor dietary and poor oral health habits $(1,2)$. A more alarming form of ECC is termed as severe-ECC (S-ECC) depending on the age and number of teeth affected (3). Associated risk factors include microbiological, dietary and environmental (4). ECC can be prevented by decreasing the bacterial count of the child's caregiver (mother), minimizing bacterial transmission causing tooth decay and by oral health education of the parents (1). Maternal oral hygiene is important for prevention of vertical transmission. Some studies also noted a horizontal transmission of infection from fathers, siblings and other members of the family $(2,5)$.

Prolonged and frequent consumption of formula milk, breast milk or sugary beverages are primary dietary risk factors in ECC. Use of nursing bottle and "Sippy cups" enhances the exposure to lactose (2). Night time bottle feeding increases the risk of caries as the salivary flow decreases during sleep and the oral clearance is low. Thus, an anterior caries pattern 
is commonly observed in children using a bottle $(6$, 7). Many studies showed that milk-bottle feeding at night is a strong risk factor for the development of $\operatorname{ECC}(2,7)$. In a Southeast Asian population, the consumption of sugars and pre-chewed rice, nocturnal breastfeeding after the age of 12 months posed a risk for developing ECC (8). Regional differences in oral hygiene and feeding practices due to existing cultural beliefs can lead to variations in caries patterns and severity (9).

Environmental factors affecting the severity of ECC include caregiver social status, poor economic conditions, ethnicity, and education level $(4,10)$. There was an inclination towards consuming increased sugary foods among children living in poor socio-economic areas (1). Based on National Oral Health Plan for Malaysia 2011-2020, the prevalence of dental caries among school children (5 yearsold) has decreased from $87.1 \%$ in 1995 to $76.2 \%$ in 2005(11). However, the mean dft (decayed, missing and filling) did not show significant changes; from 5.8 in 1995 to 5.5 in 2005 (12). This indicates high prevalence and severity of dental caries among young children in Malaysia (11) (12). Parents showed relatively good knowledge, but poor attitude and practice towards the oral health of their children (13). In another study, habits of allowing infants to sleep with breast nipple in the mouth and late start of tooth brushing were associated with the prevalence of ECC in Malaysia (14). More detailed information on bottle feeding and oral hygiene practices in children with ECC is needed to understand the cultural habits in this region.

The aim of this study was to identify the oral hygiene practices and the feeding pattern of children with ECC and their association with the severity of caries.

\section{Materials and Methods}

A close-ended questionnaire consisting of 32 items addressing bottle feeding pattern and oral hygiene practices among children aged 3-5 years was designed. The questionnaire included a section on socio-demographic data to assess the socioeconomic status, educational level and occupation of the parent. The questionnaire was constructed in English and later translated into Bahasa Melayu, the local language and back-translated to English. The questionnaire was pretested on 5 randomly selected subjects before conducting the study.

In this cross-sectional study, a convenient sample of 32 parents accompanying children aged 3-5 years with early childhood caries attending the Primary care unit of a public university hospital for a routine dental checkup from June - August 2015 were invited to participate in the study. Children of the same age group who had sound primary dentition or medical problems were excluded from the study. After obtaining written consent from the parent, the questionnaires were handed out to be completed by the parent/caregiver and collected immediately. Parents who required help in reading were assisted. The child was clinically examined by trained post graduate students and the dft score was recorded using the WHO criteria (15). Ethical clearance was obtained from the Ethics Committee of the University.

The data was recorded and analyzed using Statistical Package for Social Sciences version 12.0.1 software (SPSS Inc., Chicago, IL, USA). Patients were categorized into 2 groups based on severity of ECC, which was classified as ECC $<5$ and S-ECC $\geq 6$. Descriptive statistics included computation of percentages, means, and standard deviations. The association between the variables and the severity of ECC was also analyzed using chi-square test. Fisher's Exact test was used to analyze the data if the assumptions for chi-square test were not met.

\section{Results}

Demographic characteristics of the parents are shown in Table 1. Most of the parents who completed the questionnaire were mothers of children and aged more than 30 years. Most of the parents were employed outside the home and specified college/ university as their highest education level.

Table 1: Demographic Characteristics of Parents

\begin{tabular}{llll}
\hline Variables & & $\mathrm{n}$ & $(\%)$ \\
\hline $\begin{array}{l}\text { Parents who } \\
\text { completed the }\end{array}$ & Father & 9 & $(28.1 \%)$ \\
questionnaire & Mother & 23 & $(71.9 \%)$ \\
& $21-30$ years old & 6 & $(18.7 \%)$ \\
& $31-40$ years old & 22 & $(68.8 \%)$ \\
& $>40$ years old & 4 & $(12.5 \%)$ \\
Education & Secondary & 8 & $(25 \%)$ \\
& College/ & 24 & $(75 \%)$ \\
Occupation & University & & \\
Homemaker & 6 & $(18.8 \%)$ \\
No. of children in & Working & 26 & $(81.3 \%)$ \\
family & 1 & 5 & $(15.6 \%)$ \\
& 2 & 14 & $(43.8 \%)$ \\
& 3 & 8 & $(25 \%)$ \\
& $>3$ & 5 & $(15.6 \%)$ \\
\hline
\end{tabular}

Demographic characteristics of the children are shown in Table 2. Most of the children were 5 yearsold, predominantly boys. In addition, $75 \%$ of the 
children had another significant caregiver and about half of them were the eldest in the family.

Table 2: Demographic Characteristics of Children

\begin{tabular}{llll}
\hline Variable & & $\mathrm{n}$ & $(\%)$ \\
\hline \multirow{3}{*}{ Age } & 3 years old & 10 & $(31.3 \%)$ \\
& 4 years old & 9 & $(28.1 \%)$ \\
Gender & 5 years old & 13 & $(40.6 \%)$ \\
& Boy & 19 & $(59.4 \%)$ \\
Ethnicity & Girl & 13 & $(40.6 \%)$ \\
& Malay & 28 & $(87.5 \%)$ \\
Another significant & Chinese & 3 & $(9.4 \%)$ \\
caregiver & Indian & 1 & $(3.1 \%)$ \\
& None & 8 & $(25 \%)$ \\
& Relative & 6 & $(18.8 \%)$ \\
Position in the family & Baby sitter & 11 & $(34.4 \%)$ \\
& Preschool & 7 & $(21.9 \%)$ \\
& Eldest & 17 & $(53.1 \%)$ \\
& Middle & 8 & $(25 \%)$ \\
& Last & 7 & $(21.9 \%)$ \\
\hline
\end{tabular}

Current feeding habits of the children are shown in Table 3. Half of the children were still bottle fed, while all of them had started eating solid food. Besides, 22 out of 32 children had dft more than 5.

Table 4 shows the bottle-feeding pattern of the children. A total of twenty-eight children had experienced bottle feeding, 17 of whom were bottle feeding at the time of the study, while 11 children had stopped the habit at the time of the study. Most of them were introduced to bottle feeding before their first birthday. In addition, most of them were given milk in a bottle 3 times or more times daily and at night time before sleep. Besides, half of them took 10 to 30 minutes to complete one feed from a bottle. Among all respondents that had history of bottle feeding, 11 of them had stopped bottle feeding, most of them being weaned off at the age of 5 .

Oral hygiene practices of the children are shown in Table 5. Half of the respondents started tooth brushing between ages 1 and 2 with majority brushing every day and being supervised by their parents. Most of them had no oral hygiene practice after consuming milk/ sugary drinks and never shared a spoon or bottle with other siblings. Most of the variables showed no significant association with dft (severity of caries) except the current bottlefeeding habits which was significantly associated to the severity of caries $(p=0.02)$.

\section{Discussion}

The mean dft in this study was 8.88 which was higher compared to the national mean dft of children in Malaysia (12), and most other countries reporting ECC $(9,16-19)$ (Table 7). Since the sample for this study was taken from patients attending a hospital setting, it was more likely for them to have a higher burden of dental disease. Similar sample selection was noted in other studies $(19,20)$. However, many other studies have compared children from both high and low caries risk population (21-24). Based on

Table 3: Current Feeding Habits and dft among the children

\begin{tabular}{|c|c|c|c|c|c|c|c|c|c|}
\hline \multirow{2}{*}{\multicolumn{2}{|c|}{ Variables }} & \multicolumn{2}{|c|}{$\begin{array}{l}3 \text { years old } \\
(n=10)\end{array}$} & \multicolumn{2}{|c|}{$\begin{array}{c}4 \text { years old } \\
(n=9)\end{array}$} & \multicolumn{2}{|c|}{$\begin{array}{c}5 \text { years old } \\
(n=13)\end{array}$} & \multicolumn{2}{|c|}{$\begin{array}{c}\text { Total } \\
(\mathrm{N}=32)\end{array}$} \\
\hline & & \multicolumn{2}{|c|}{$\mathrm{n}(\%)$} & \multicolumn{2}{|c|}{$\mathrm{n}(\%)$} & \multicolumn{2}{|c|}{ n (\%) } & \multirow[b]{2}{*}{7} & \multirow[b]{2}{*}{$(21.9 \%)$} \\
\hline Breastfeeding & & 2 & $(20 \%)$ & 3 & $(33.3 \%)$ & 2 & $(15.4 \%)$ & & \\
\hline Bottle feeding & & 5 & $(50 \%)$ & 5 & $(55.6 \%)$ & 7 & $(53.8 \%)$ & 17 & $(53.1 \%)$ \\
\hline $\begin{array}{l}\text { Breast and bottle } \\
\text { feeding }\end{array}$ & & 3 & $(30 \%)$ & 2 & $(22.2 \%)$ & 4 & $(30.8 \%)$ & 9 & $(28.1 \%)$ \\
\hline Trained using cup & & 10 & $(100 \%)$ & 9 & $(100 \%)$ & 13 & $(100 \%)$ & 32 & $(100 \%)$ \\
\hline Solid food & & 10 & $(100 \%)$ & 9 & $(100 \%)$ & 13 & $(100 \%)$ & 32 & $(100 \%)$ \\
\hline \multirow{3}{*}{$\begin{array}{l}\text { Introduction to solid } \\
\text { food }\end{array}$} & $<1$-year-old & 1 & $(10 \%)$ & 2 & $(22.2 \%)$ & 4 & $(30.8 \%)$ & 7 & $(21.9 \%)$ \\
\hline & $\begin{array}{l}1 \text { to }<2 \text { years } \\
\text { old }\end{array}$ & 8 & $(80 \%)$ & 5 & $(55.6 \%)$ & 7 & $(53.8 \%)$ & 20 & $(62.5 \%)$ \\
\hline & $\begin{array}{l}2 \text { to }<3 \text { years } \\
\text { old }\end{array}$ & 1 & $(10 \%)$ & 2 & $(22.2 \%)$ & 2 & $(15.4 \%)$ & 5 & $(15.6 \%)$ \\
\hline Pre-chewed food & & 2 & $(20 \%)$ & 4 & $(44.4 \%)$ & 3 & $(23.1 \%)$ & 9 & $(28.1 \%)$ \\
\hline Blended food & & 1 & $(10 \%)$ & 5 & $(55.6 \%)$ & 1 & $(7.7 \%)$ & 7 & $(21.9 \%)$ \\
\hline \multirow[t]{2}{*}{ dft } & $<5$ & 3 & $(30 \%)$ & 2 & $(20 \%)$ & 5 & $(50 \%)$ & 10 & $(31.3 \%)$ \\
\hline & $\geq 6$ & 7 & $(31.8 \%)$ & 7 & $(31.8 \%)$ & 8 & $(36.4 \%)$ & 22 & $(68.8 \%)$ \\
\hline
\end{tabular}


Table 4: Bottle Feeding Pattern among the children

\begin{tabular}{|c|c|c|c|c|c|}
\hline \multicolumn{2}{|l|}{ Variables } & \multirow{2}{*}{$\frac{n}{11}$} & \multirow{2}{*}{$\frac{(\%)}{(39.3 \%)}$} & \multicolumn{2}{|c|}{ Total $(\mathrm{N}=28)$} \\
\hline \multirow{3}{*}{ Introduction to bottle feeding } & $<6$ months & & & 28 & $(100 \%)$ \\
\hline & 6 months - <1-year-old & 12 & $(42.9 \%)$ & & \\
\hline & 1 year old- 2-year-old & 5 & $(17.9 \%)$ & & \\
\hline \multirow{5}{*}{$\begin{array}{l}\text { Frequency of giving breast/formula milk } \\
\text { daily }\end{array}$} & Never & 0 & $(0.00)$ & 28 & $(100 \%)$ \\
\hline & Occasionally & 2 & $(7.1 \%)$ & & \\
\hline & Once & 0 & $(0.00)$ & & \\
\hline & Twice & 1 & $(3.6 \%)$ & & \\
\hline & 3 times & 5 & $(17.9 \%)$ & & \\
\hline \multirow{5}{*}{ Frequency of giving water drink daily } & $>3$ times & 20 & $(71.4 \%)$ & & \\
\hline & Never & 9 & $(32.1 \%)$ & 28 & $(100 \%)$ \\
\hline & Occasionally & 5 & $(17.9 \%)$ & & \\
\hline & Once & 0 & $(0.00)$ & & \\
\hline & Twice & 3 & $(10.7 \%)$ & & \\
\hline \multirow{7}{*}{ Frequency of giving juice/sugary drink } & 3 times & 2 & $(7.1 \%)$ & & \\
\hline & $>3$ times & 9 & $(32.1 \%)$ & & \\
\hline & Never & 11 & $(39.3 \%)$ & 28 & $(100 \%)$ \\
\hline & Occasionally & 7 & $(25 \%)$ & & \\
\hline & Once & 4 & $(14.3 \%)$ & & \\
\hline & Twice & 1 & $(3.6 \%)$ & & \\
\hline & 3 times & 1 & $(3.6 \%)$ & & \\
\hline \multirow{4}{*}{$\begin{array}{l}\text { Frequency of putting child to sleep using } \\
\text { bottle }\end{array}$} & $>3$ times & 4 & $(14.3 \%)$ & & \\
\hline & Never & 7 & $(25 \%)$ & 28 & $(100 \%)$ \\
\hline & Sometimes & 5 & $(17.9 \%)$ & & \\
\hline & Every night & 16 & $(57.1 \%)$ & & \\
\hline \multirow{2}{*}{$\begin{array}{l}\text { Frequency of feeding the child in the } \\
\text { middle of the night using bottle }\end{array}$} & Never & 6 & $(21.4 \%)$ & 28 & $(100 \%)$ \\
\hline & Sometimes & 13 & $(46.4 \%)$ & & \\
\hline \multirow{4}{*}{ Time to complete one feed } & Every night & 9 & $(32.1 \%)$ & & \\
\hline & $<10$ minutes & 11 & $(39.3 \%)$ & 28 & $(100 \%)$ \\
\hline & $10-30$ minutes & 14 & $(50 \%)$ & & \\
\hline & $>30$ minutes & 3 & $(10.7 \%)$ & & \\
\hline \multirow{5}{*}{ Has the child stopped bottle feeding? } & Yes & 11 & $(39.3 \%)$ & 28 & $(100 \%)$ \\
\hline & 1 year old & 1 & $(3.6 \%)$ & & \\
\hline & 2 years old & 1 & $(3.6 \%)$ & & \\
\hline & 3 years old & 4 & $(14.3 \%)$ & & \\
\hline & 4 years old & 2 & $(7.1 \%)$ & & \\
\hline \multirow{6}{*}{ Expected age to wean off bottle } & 5 years old & 3 & $(10.7 \%)$ & & \\
\hline & No & 17 & $(60.7 \%)$ & & \\
\hline & 3 years old & 2 & $(7.1 \%)$ & & \\
\hline & 4 years old & 3 & $(10.7 \%)$ & & \\
\hline & 5 years old & 7 & $(25 \%)$ & & \\
\hline & 6 years old & 5 & $(17.9 \%)$ & & \\
\hline
\end{tabular}


Table 5: Oral Hygiene Practices of the children

\begin{tabular}{|c|c|c|c|c|c|c|c|c|c|}
\hline \multirow[t]{2}{*}{ Variables } & & \multicolumn{2}{|c|}{$\begin{array}{l}3 \text { years old } \\
(n=10)\end{array}$} & \multicolumn{2}{|c|}{$\begin{array}{l}4 \text { years old } \\
(n=9)\end{array}$} & \multicolumn{2}{|c|}{$\begin{array}{l}5 \text { years old } \\
(n=13)\end{array}$} & \multicolumn{2}{|c|}{$\begin{array}{c}\text { Total } \\
(\mathrm{N}=32)\end{array}$} \\
\hline & & $\mathrm{n}$ & $(\%)$ & $\mathrm{n}$ & $(\%)$ & $\mathrm{n}$ & $(\%)$ & $\mathrm{n}$ & $(\%)$ \\
\hline \multirow{4}{*}{$\begin{array}{l}\text { Introduction to tooth } \\
\text { brushing }\end{array}$} & 6 months- $<1$ - years-old & 5 & $(50 \%)$ & 2 & $(22.2 \%)$ & 3 & $(23.1 \%)$ & 10 & $(31.3 \%)$ \\
\hline & 1 years old- $<2$ years old & 4 & $(40 \%)$ & 6 & $(66.7 \%)$ & 6 & $(46.2 \%)$ & 16 & $(50 \%)$ \\
\hline & 2 years old $-<3$ years old & 1 & $(10 \%)$ & 0 & $(0.00)$ & 1 & $(7.7 \%)$ & 2 & $(37.5 \%)$ \\
\hline & 3 years old- 4 years old & 0 & $(0.00)$ & 1 & $(11.1 \%)$ & 3 & $(23.1 \%)$ & 4 & $(12.5 \%)$ \\
\hline \multirow{4}{*}{$\begin{array}{l}\text { Frequency of tooth } \\
\text { brushing }\end{array}$} & Rarely & 0 & $(0.00)$ & 1 & $(11.1 \%)$ & 0 & $(0.00)$ & 1 & $(3.1 \%)$ \\
\hline & Once in 2-3 days & 1 & $(10 \%)$ & 2 & $(22.2 \%)$ & 1 & $(7.7 \%)$ & 4 & $(12.5 \%)$ \\
\hline & Every day (once) & 3 & $(30 \%)$ & 3 & $(33.3 \%)$ & 2 & $(15.4 \%)$ & 8 & $(25 \%)$ \\
\hline & Every day (twice) & 6 & $(60 \%)$ & 3 & $(33.3 \%)$ & 10 & $(76.9 \%)$ & 19 & $(59.4 \%)$ \\
\hline \multirow[t]{4}{*}{ Supervised tooth brushing } & Never & 0 & $(0.00)$ & 0 & $(0.00)$ & 2 & $(15.4 \%)$ & 2 & $(6.3 \%)$ \\
\hline & Sometimes & 3 & $(30 \%)$ & 3 & $(33.3 \%)$ & 3 & $(23.1 \%)$ & 9 & $(28.1 \%)$ \\
\hline & Every day & 7 & $(70 \%)$ & 6 & $(66.7 \%)$ & 8 & $(61.5 \%)$ & 21 & $(65.6 \%)$ \\
\hline & No particular practice & 6 & $(60 \%)$ & 6 & $(66.7 \%)$ & 8 & $(61.5 \%)$ & 20 & $(62.5 \%)$ \\
\hline \multirow{2}{*}{$\begin{array}{l}\text { Normal practice after } \\
\text { consuming milk }\end{array}$} & Drink water & 4 & $(40 \%)$ & 2 & $(22.2 \%)$ & 4 & $(30.8 \%)$ & 10 & $(31.3 \%)$ \\
\hline & Brush teeth & 0 & $(0.00)$ & 1 & $(11.1 \%)$ & 1 & $(7.7 \%)$ & 2 & $(6.3 \%)$ \\
\hline \multirow{5}{*}{$\begin{array}{l}\text { Normal practice after } \\
\text { consuming sweet food/ } \\
\text { beverage }\end{array}$} & No particular practice & 6 & $(60 \%)$ & 3 & $(33.3 \%)$ & 6 & $(46.2 \%)$ & 15 & $(46.9 \%)$ \\
\hline & Rinse mouth & 1 & $(10 \%)$ & 1 & $(11.1 \%)$ & 1 & $(7.7 \%)$ & 3 & $(9.4 \%)$ \\
\hline & Drink water & 3 & $(30 \%)$ & 5 & $(55.6 \%)$ & 5 & $(38.5 \%)$ & 13 & $(40.6 \%)$ \\
\hline & Brush teeth & 0 & $(0.00)$ & 0 & $(0.00)$ & 1 & $(7.7 \%)$ & 1 & $(3.1 \%)$ \\
\hline & Adult toothpaste & 0 & $(0.00)$ & 0 & $(0.00)$ & 4 & $(30.8 \%)$ & 4 & $(12.5 \%)$ \\
\hline \multirow[t]{2}{*}{ Type of toothpaste } & Children toothpaste & 10 & $(100 \%)$ & 9 & $(100 \%)$ & 9 & $(69.2 \%)$ & 28 & $(87.5 \%)$ \\
\hline & No other aid & 10 & $(100 \%)$ & 9 & $(100 \%)$ & 11 & $(84.6 \%)$ & 30 & $(92.8 \%)$ \\
\hline \multirow{6}{*}{$\begin{array}{l}\text { Spoon/bottle sharing } \\
\text { without washing between } \\
\text { child and parents/siblings }\end{array}$} & Mouthwash & 0 & $(0.00)$ & 0 & $(0.00)$ & 2 & $(15.4 \%)$ & 2 & $(6.3 \%)$ \\
\hline & Dental floss & 0 & $(0.00)$ & 0 & $(0.00)$ & 0 & $(0.00)$ & & \\
\hline & Never/ Rarely & 8 & $(80 \%)$ & 8 & (88.9\%) & 9 & $(69.2 \%)$ & 25 & $(78.1 \%)$ \\
\hline & Once in 2-3 days & 0 & $(0.00)$ & 0 & $(0.00)$ & 2 & $(15.4 \%)$ & 2 & $(6.3 \%)$ \\
\hline & Every day (once) & 1 & $(10 \%)$ & 0 & $(0.00)$ & 1 & $(7.7 \%)$ & 2 & $(6.3 \%)$ \\
\hline & Every day (twice) & 1 & $(10 \%)$ & 1 & $(11.1 \%)$ & 1 & $(7.7 \%)$ & 3 & $(9.4 \%)$ \\
\hline $\begin{array}{l}\text { Sharing toothbrush with } \\
\text { other siblings }\end{array}$ & & 1 & $(10 \%)$ & 0 & $(0.00)$ & 0 & $(0.00)$ & 1 & $(3.1 \%)$ \\
\hline
\end{tabular}

our study, age, occupation and parental education had no significant association with severity of ECC $(p>0.05)$. Elsewhere, parental education level was a major risk factor for ECC (22). In Australia, there was a significant increase in the prevalence of ECC in children of younger mothers, less than 24 years (9). Prevalence and severity of ECC significantly increased with fourth or higher order children while we found no association between child order and severity of caries (9).

There was an increase in prevalence of caries in children with prolonged bottle feeding beyond two years of age $(9,16)$. In our study, $87.5 \%$ of the children had a history of bottle feeding with $53.1 \%$ still being bottle fed despite being trained to eat solid food and use a cup (Table 3). Current bottle-feeding habit was statistically significant with the severity of caries in our study $(\mathrm{P}<0.05)$. Among children that had history of bottle feeding, only $39.3 \%$ had stopped with the mean age at weaning being $3.45 \pm 1.29$ years, indicating prolonged bottle-feeding habit in this sample. Similar age at weaning was observed in Bangpakong, Thailand ( $3.1 \pm 0.6$ years old) (25) and Philippines (26). This implies that most parents/ caretakers either did not follow or were not aware of the recommended weaning time. According to the 
Table 6: Association between dft and Demographic Characteristics/Bottle Feeding Pattern/Oral Hygiene Practices

\begin{tabular}{|c|c|c|}
\hline Variables & $\mathrm{p}$ & Significance \\
\hline Age of parents & 0.142 & NS \\
\hline Parent's education & 1.000 & NS \\
\hline Parent's occupation & 0.346 & NS \\
\hline Caregiver & 0.218 & NS \\
\hline Position of child in family & 0.450 & NS \\
\hline $\begin{array}{l}\text { Current feeding habit: } \\
\text { bottle feeding }\end{array}$ & 0.021 & $S$ \\
\hline $\begin{array}{l}\text { Current habit: pre- } \\
\text { chewed food/tooth } \\
\text { brushing or spoon } \\
\text { sharing }\end{array}$ & 1.000 & NS \\
\hline $\begin{array}{l}\text { Age to start bottle } \\
\text { feeding }\end{array}$ & 0.668 & NS \\
\hline $\begin{array}{l}\text { Frequency of giving milk } \\
\text { in bottle daily }\end{array}$ & 0.551 & NS \\
\hline $\begin{array}{l}\text { Frequency of giving } \\
\text { juice/sugary drink in } \\
\text { bottle daily }\end{array}$ & 0.357 & NS \\
\hline Night time bottle feeding & 0.574 & NS \\
\hline $\begin{array}{l}\text { Time to complete one } \\
\text { feed }\end{array}$ & 0.668 & NS \\
\hline Weaned from bottle & 0.076 & NS \\
\hline $\begin{array}{l}\text { Age to stop bottle } \\
\text { feeding }\end{array}$ & 0.455 & NS \\
\hline $\begin{array}{l}\text { Age to start tooth } \\
\text { brushing }\end{array}$ & 1.000 & NS \\
\hline $\begin{array}{l}\text { Supervised tooth } \\
\text { brushing }\end{array}$ & 0.703 & NS \\
\hline $\begin{array}{l}\text { Frequency of tooth } \\
\text { brushing }\end{array}$ & 0.155 & NS \\
\hline $\begin{array}{l}\text { Normal practice after } \\
\text { consuming milk/sweet } \\
\text { drink }\end{array}$ & 1.000 & NS \\
\hline
\end{tabular}

Table 7: Comparison of Mean dft from different nations

\begin{tabular}{llllll}
\hline Countries & Mean dft & & & \\
\hline China & $9.2 \pm 3.6$ & & & \\
Malaysia & 1995 & 2005 & 1988 & 1997 & 2007 \\
& 5 -year-old & 6 -year-old & \\
& 5.8 & 5.5 & 5.7 & 4.1 & 3.6 \\
Australia & $1.4 \pm 2.77$ & & & \\
India & $2.03 \pm 2.99$ & & & \\
Nigeria & $0.735 \pm 2.07$ & & & \\
Malaysia (this study) & 8.8 & & & & \\
\hline
\end{tabular}

Ministry of Health, Malaysia, bottle feeding should be discontinued by 12 to 14 months of age. The most common reason of prolonged bottle feeding is the child's refusal to wean (25). There is a need for oral health promotion strategies that include specific messages regarding time for weaning the bottle and practical advice for parents /caregivers of children with prolonged bottle feeding.

According to AAPD, the risk for ECC is related to repetitive breast-feeding times and prolonged exposure to fermentable carbohydrates (3). Similar effects can be extrapolated to bottle feeding. Among children with history of bottle feeding in this study, $71.4 \%$ consumed milk using bottle more than 3 times a day, $72 \%$ practiced night time bottle feeding which was higher than the study done in Thailand (25). Current night time bottle feeding habits in our study reflected the attitude among parents elsewhere in Malaysia, where majority of the parents disagreed that night time bottle feeding, and prolonged, frequent bottle feeding can cause tooth decay (27). Of those children who bottle fed at night, $64.28 \%$ had $\mathrm{dft}$ more than 5 . Besides, $60.7 \%$ drank sugary drink/ juice using the bottle daily which was also higher than Kelantan, South Africa (19), Brazil (24), China (18) and north Brisbane (7). This ascertains that majority of the parents followed high caries risk practices and were probably unaware of the detrimental nature of these habits (18). Regarding time taken to finish one feed from the bottle, majority of the children took 10 to 30 minutes in our study, another factor increasing the risk for caries.

Among all the children in our study, only $31.3 \%$ started brushing their teeth before they turned one-year old. However, there was no significant association with the severity of caries $(p>0.05)$. In a study by Hallett et al, the ECC experience of children who started tooth brushing earlier (at age of 12 months) was significantly lower compared to those who started tooth brushing at the age of 13 months or later (9). Ministry of Health Malaysia recommends that children should practice regular tooth brushing as soon as they have teeth, twice daily (28). Regarding frequency of tooth brushing in our study, $84.4 \%$ of the children were found to brush their teeth at least once every day while $59.38 \%$ brushed twice daily, with $65.6 \%$ being supervised. Brushing frequency was also not significantly associated with the severity of ECC in this study, similar to the findings in Kanpur, India (16), Latvia (29) and Kerala, India (30), China, Southern Brazil (24) and Lagos, Nigeria (17). On the contrary, low frequency of tooth brushing and improper tooth brushing technique among the children was significantly associated with S-ECC in another study (31). In addition, the low frequency of tooth brushing among the children was also significantly associated with low frequency tooth brushing habits of the caretakers (31). The number of children that had no particular oral hygiene 
practice after consumption of milk sweet drinks or food was $43.8 \%$, compared to that in Taiwan where it was $95 \%$ (31). About $40 \%$ of the children consumed pre-chewed rice and/or shared spoons or feeding utensils with their parents or siblings daily. This allows both horizontal and vertical transmission of bacteria, additionally increasing the risk for caries in these children (3). Based on study in Kelantan, Malaysia, most parents did not know that tooth decay may be caused by bacteria transmission through sharing feeding utensils (27). Similar practice of prechewing of rice was also found in other studies in the Asian region (8). Cultural practices and social beliefs of a region account for an important aspect in determining oral health status (9). Certain practices are followed for generations and remain persistent, overlooking the relevant information available in reliable resources.

There were several high-risk factors in this group of children with SECC and ECC. However, only one significant risk factor was identified between the $E C C$ and S-ECC group due to majority being in the S-ECC group. Since dental caries is a multifactorial disease, many other risk factors such as snacking patterns and active dental diseases in caregivers were not recorded and analysed, therefore being a limitation in the study. Being a preliminary study with a small sample, further studies should enquire whether similar habits are observed in larger samples of children with and without ECC and reasons for prolonged feeding habits. In addition, studies regarding the knowledge and perception of the parents towards feeding habits of their child and its effects on oral health may also be conducted.

\section{Conclusion}

In this study, prolonged bottle-feeding habit is a major risk factor for early childhood caries. Besides bottle feeding, a number practices with high risk for caries were also noted, including factors promoting vertical and horizontal transmission of bacteria. However, many factors did not show any significant association with the severity of ECC.

\section{References}

1. Colak H, Dulgergil CT, Dalli M, Hamidi MM. Early childhood caries update: A review of causes, diagnoses, and treatments. J Nat Sci Biol Med 2013;4:29-38.

2. Berkowitz RJ. Causes, treatment and prevention of early childhood caries: a microbiologic perspective. J Can Dent Assoc 2003;69:304-7.

3. American Academy of Pediatric Dentistry. Policy on early childhood caries (ECC): classifications, consequences, and preventive strategies. Pediatr Dent 2014;37:50-53.

4. Kawashita Y, Kitamura M, Saito T. Early childhood caries. Int J Dent 2011;2011:725320.

5. Kozai K, Nakayama R, Tedjosasongko U, Kuwahara S, Suzuki J, Okada M, et al. Intrafamilial distribution of mutans streptococci in Japanese families and possibility of fatherto-child transmission. Microbiol Immunol 1999;43:99-106.

6. Ripa LW. Nursing caries: a comprehensive review. Pediatr Dent 1988;10:268-82.

7. Hallett KB, O'Rourke PK. Pattern and severity of early childhood caries. Community Dent Oral Epidemiol 2006;34:25-35.

8. van Palenstein Helderman WH, Soe $W$, van 't Hof MA. Risk factors of early childhood caries in a Southeast Asian population. J Dent Res 2006;85:85-8.

9. Hallett K, O'Rourke P. Social and behavioural determinants of early childhood caries. Aust Dent J 2003;48:27-33.

10. Ramos-Gomez FJ, Weintraub JA, Gansky $\mathrm{SA}$, Hoover $\mathrm{Cl}$, Featherstone JD. Bacterial, behavioral and environmental factors associated with early childhood caries. J Clin Pediatr Dent 2002;26:165-73.

11. Oral Health Division Ministry of Health. Guidelines Early Childhood Oral Healthcare. In: Government Printers, Kuala Lumpur; 2008.

12. Oral Health Division Ministry of Health Malaysia. National Oral Health Plan for Malaysia 20112020 Malaysia; 2011.

13. Witjaksono. W, TinOo MM, Kechik KA. Nursing habits and early childhood caries in children attending Hospital University Science Malaysia (HUSM). Dent J (Majalah Kedokteran Gigi) 2006;39:54-58.

14. Corp I. IBM SPSS statistics for windows, version 22.0. Armonk, NY: IBM Corp;2013.

15. World Health Organization. Oral health surveys: Basic methods. 2013.

16. Prakasha Shrutha S, Vinit GB, Giri KY, Alam $S$. Feeding practices and early childhood caries: a cross-sectional study of preschool children in kanpur district, India. ISRN Dent 2013;2013:275193.

17. Olatosi OO, Inem $V$, Sofola OO, Prakash P, Sote EO. The prevalence of early childhood caries and its associated risk factors among preschool children referred to a tertiary care institution. Niger J Clin Pract 2015;18:493-501. 
18. Qin M, Li J, Zhang S, Ma W. Risk factors for severe early childhood caries in children younger than 4 years old in Beijing, China. Pediatr Dent 2008;30:122-8.

19. Mohamed N, Barnes J. Characteristics of children under 6 years of age treated for early chidhood caries in South Africa. J Clinic Pediatr Dent 2008;32:247-52.

20. Perera PJ, Fernando MP, Warnakulasooriya TD, Ranathunga N. Effect of feeding practices on dental caries among preschool children: a hospital based analytical cross sectional study. Asia Pac J Clin Nutr 2014;23:272-7.

21. Tiberia MJ, Milnes AR, Feigal RJ, Morley KR, Richardson DS, Croft WG, et al. Risk factors for early childhood caries in Canadian preschool children seeking care. Pediatr Dent 2007;29:201-8.

22. Congiu G, Campus G, Sale S, Spano G, Cagetti MG, Luglie PF. Early childhood caries and associated determinants: a crosssectional study on Italian preschool children. J Public Health Dent 2014;74:147-52.

23. Prakash $P$, Subramaniam $P$, Durgesh $B H$, Konde S. Prevalence of early childhood caries and associated risk factors in preschool children of urban Bangalore, India: A crosssectional study. Eur J Dent 2012;6:141-52.

24. Feldens CA, Giugliani ER, Vigo A, Vitolo MR. Early feeding practices and severe early childhood caries in four-year-old children from southern Brazil: a birth cohort study. Caries Res 2010;44:445-52.

25. Suwansingha $O$, Rirattanapong P. Preschool children's caregivers' attitudes and behavior regarding bottle feeding in Bangpakong, Chachoengsao. J Int Soc Prev Community Dent 2014;4:S93-8.
26. Carino KM, Shinada K, Kawaguchi Y. Early childhood caries in northern Philippines. Community Dent Oral Epidemiol 2003;31:81-9.

27. Mani SA, John J, Ping WY, Ismail NM. Early Childhood Caries: Parent's Knowledge, Attitude and Practice Towards Its Prevention in Malaysia. In: Virdi PM, editor. Oral Health Care - Pediatric, Research, Epidemiology and Clinical Practices: InTech; 2012.

28. Oral Health Division Ministry of Health Malaysia. Clinical Practice Guidelines Management of Severe Early Childhood Caries. In: Government printers, Malaysia; 2012. pp. 13.

29. Bjarnason S, Care R, Berzina S, Brinkmane A, Rence I, Mackevica I, et al. Caries experience in Latvian nursery school children. Community Dent Oral Epidemiol 1995;23:138-41.

30. Kuriakose S, Joseph E. Caries prevalence and its relation to socio-economic status and oral hygiene practices in 600 pre-school children of Kerala-India. J Indian Soc Pedod Prev Dent 1999;17:97-100.

31. Hsieh HJ, Huang ST, Tsai CC, Hsiao SY. Toothbrushing habits and risk indicators of severe early childhood caries among aboriginal Taiwanese. Asia Pac J Public Health 2014;26:238-47.

\section{Corresponding author:}

\section{Dr. Shani Ann Mani}

Lecturer,

Department of Paediatric Dentistry and Orthodontics, Faculty of Dentistry,

University of Malaya,

50603 Kuala Lumpur

Malaysia.

Email: shani@um.edu.my 